\title{
The Role Of Board Characteristics In Mitigating Management Opportunism: The Case Of Real Earnings Management
}

Dorra Talbi, Université de Kairouan, Tunisia

Mohamed Ali Omri, Northern Borders University, Saudi Arabia

Khaled Guesmi, IPAG Business School, \& University of Paris Ouest Nanterre La Defense, France

Zied Ftiti, EDC Paris Business School, OCRE-Lab, Paris-France \& High Institute of Management of Tunis, Tunisia

\begin{abstract}
This study seeks to provide empirical evidence of the efficacy of board characteristics in constraining management opportunism, measured by real earnings management. The paper uses regression analysis to document empirical evidence regarding the impact of the independence of boards of directors and the independence of committees on real earnings management in 7,481 US firms over the period 2000 to 2009. This study contributes to empirical studies on the role of corporate governance in financial reporting quality by demonstrating the role of the independence of boards of directors and the independence of committees in constraining real earnings management. These results should contribute to providing an orientation for future regulators regarding possible amendments, especially in the wake of the current financial crisis.
\end{abstract}

Keywords: Real Earnings Management; Board Of Directors; Audit Committee; Managerial Myopia; Corporate Governance

\section{INTRODUCTION}

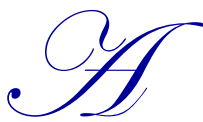

number of financial scandals occurred around the world towards the end of 2000 (e.g., Enron, WorldCom and Tyco International), and, with the advent of successive financial crises (tech bubble, subprime), the global economic landscape has changed dramatically. All these circumstances have cast doubt on the quality of the financial information published by companies and have revived debates that academics, experts and legislators believed had already been solved, debates about the integrity of accounting information and the role of governance. The enactments of the Sarbanes-Oxley act (SOX), described by some specialists to be too restrictive (Demski, 2004; Ewert and Wagenhofer, 2005), may restore investor confidence and improve the quality of accounting information.

Prior accounting literature identifies two alternative ways to manage earnings: accruals and real activities (Gunny, 2005; Roychowdhury, 2006; Cohen et al., 2008). Accruals manipulation has been extensively studied in previous work, while real earnings management has remained a largely unexplored area.

In a theoretical work using a rational expectations model, Ewert and Wagenhofer (2005) demonstrate that when firms are subject to a tightening regulation to improve their earnings quality may actually lead managers to switch to other manipulation tools like real earnings management. Empirical studies validate these theoretical predictions. Cohen et al. (2008) examine the level of earnings management for two periods: pre and post SOX enactment. They confirm that the level of accruals manipulation declined after the passage of SOX, while real activities manipulation increased for the same period. Their results suggest that SOX, as a restrictive law, motives managers to switch from accounting to real activities manipulations because the later are considered to be distinguishable and constrained. Roychowdhury (2006), Zang (2012) and Chan et al. (2014) also show that managers prefer using the real activities manipulations when their accounting flexibility is reduced by a tighter scrutiny. 
Certainly an increase in earnings, will lead to a higher valuation of the firm and consequently will increase the value of manger' stock-based option compensation (Chan et al., 2014). Consequently, it will also mislead the different stakeholders which are concerned by firm performance (Roychowdhury, 2006; Cohen and Zarowin, 2010).

In fact, various control mechanisms could limit the opportunistic behaviour of managers (Shleifer and Vishny, 1997). From a financial perspective, the board of directors, as a statutory authority responsible for controlling and ratifying management decisions, plays an important role in the resolution of agency conflicts (Fama and Jensen, 1983). It is considered as an internal corporate governance mechanism whose efficiency has a direct impact on value creation and, consequently, on shareholder satisfaction.

The tendency of manipulating real activities to manage earnings is a challenge to corporate governance practices, so it is interesting to verify the impact of board of director and audit committee characteristics on real earnings management.

This study examines the role of characteristics of the board of directors, including board size, independence and committee composition, on the pattern of real earnings management in corporate governance. It seeks to identify the role of characteristics of the board of directors in constraining manager opportunism, especially in the case of real earnings management.

We focus our empirical analysis on a sample of 7,481 US firms listed on AMEX, NYSE and NASDAQ over the period 2000 to 2009. We first estimate real earnings management (REM) (Roychowdhury, 2006; Cohen et al., 2008; Chi et al., 2011). Following Roychowdhury (2006), we use operating activities manipulation. This includes abnormal cash flow, abnormal production and abnormal discretionary expenses. We then examine whether characteristics of the board of directors and the audit committee affect real earnings management in terms of (1) board independence, (2) audit committee independence, (3) nominating committee independence, (4) governance committee independence and (5) remuneration committee independence.

Our empirical findings are as follows. Only the boards of directors' characteristics have a significant effect on real earnings management. The number of directors is positively associated with higher levels of real earnings management. We also find that the board's independence is associated with lower levels of real earnings management. Adopting completely independent board committees does not have an effect on the level of real earnings management.

This study contributes to the literature in at least two ways. First, this study adds to the prior literature on the relation between corporate governance and financial reporting quality. Past literature has concentrated on accruals earnings management and, on the whole, research has not focused on real earnings management. Second, this paper presents evidence that increasing the number of independent members on a board leads to decreasing the level of real earnings management. At the same time, totally independent committees do not affect the level of real earnings management. This result supports the idea that stock exchange requirements were motivated more by subjective than by empirical evidence.

The remainder of this article is organized as follows. Section 2 reviews the theoretical background and prior studies. Section 3 develops the hypotheses. Section 4 describes the data collection and research methods. Section 5 reports the empirical results, and Section 6 concludes the study. 


\section{LITERATURE REVIEW}

\section{Real Earnings Management}

To mislead some stakeholders regarding underlying economic performance, managers can manipulate earnings by exercising discretion over accounting or by engaging in real activities manipulation. The review of prior literature focuses on accruals earnings manipulation and divides the motivations for earnings management into two classes: those related to contractual constraints mentioned by the positive political theory of accounting and those related to financial market pressures (Watts and Zimmerman, 1990; Healy and Walhen, 1999). Recent papers suggest that directors manipulate earnings by the manipulation of real activities for the same objectives as in the case of accrual manipulation, to increase valuations, to avoid negative contracting consequences (e.g., violation of debt covenants) and to avoid negative regulatory consequences (Graham et al., 2005).

Roychowdhury (2006) suggests that managers manipulate real activities in order to avoid missing earnings targets. Ewert and Wagenhofer (2005), in an analytical study, show that, when accounting flexibility is reduced by tightened accounting regulation, firms resort to real earnings manipulation. Cohen et al. (2008) validate empirically that, for the period after SOX, firms manipulate their earnings less by accruals and more by engaging in real activities manipulation to avoid violation of any laws or regulations. Recently, Kuo et al. (2014) find that Chinese firms, after "split share structure reform" have shifted from manipulating earnings via accruals to real earnings management because it is less detectable and under-scrutinized. Moreover, Kim et al. (2010) report that firms manipulate earnings by real activities especially when they are near the violation of debt covenants Ge et Kim (2014) report that firms engage in real earnings management in the year of issuing their new bond, in order to mislead rating agencies and consequently to have a lower bond yield spread.

However, managing real activities is more costly to firms and their stakeholders (Gunny, 2005; 2010) but is less costly to managers. In fact, when accounting information is correctly disclosed in financial statements, it is less likely to draw auditor or regulatory scrutiny (Cohen et al., 2008). Roychowdhury (2006), Cohen et al. (2008), Cohen and Zarowin (2010) and Chan et al. (2014) find that real earnings management imposes potentially great long-term costs on shareholders compared to accruals manipulation, this is due to his negative effects on future cash flows and could hurt the viability of the firm.

\section{Board Characteristics And Real Earnings Management}

Prior research has examined the role of board characteristics on real earnings management. The results to date are mixed.

Visvanathan (2008) examined the attributes of the board of directors (size, independence and duality) and the attributes of audit committees (size, independence and frequency of meetings) and their effects on real earnings management (cash flow, discretionary spending and production) using a sample of 6.759 observations over the period from 1996 to 2002. The author found limited support for assumptions about the disciplinary power exercised by these governance mechanisms on real earnings management and demonstrated their effectiveness in the case of accounting manipulation. The results show that only the independence of the board, measured by the proportion of independent directors, has a negative and significant effect on abnormal production. The author justifies the lack of relationship between governance mechanisms and management of real activities by pointing out that this technique is not an offense that external auditors will focus on. Second, real earnings management has not been adequately dealt with by empirical studies, and, therefore, there is a lack of work on detection. Adding to this is the fact that real activities manipulation is more complex and that, therefore, the establishment of methods for its detection is a difficult task. Finally, the author questions such actions, even if different management techniques produce real results as pointed out by Roychowdhury (2006), because they can generate misidentification.

The study of Osma (2008) is based on a sample of 3,438 firms. This sample consists of all firms in the UK non-financial spread across 29 different industries. The purpose of the study is to determine the role played by an independent board of directors in mitigating real earnings management, especially in terms of the manipulation of research and development expenses. For this, it uses a logistic model. The dependent variable is a binary variable 
that takes the value of 1 or 0 reflecting whether a company in question has decreased the amount invested in research and development or not. Different from Visvanathan's (2008) study and the belief in the opacity of his technique, the author demonstrates empirically that an independent board is capable to detect and limit real activities manipulation. The author also found that the dominance of outsiders on the board is likely to encourage managers to focus on the short term in the sense that a friendly board hampers management discipline.

Carcello et al. (2008) find that there is no relationship between production manipulation and the presence of an expert in the audit committee. However, there is a positive and significant relationship between the manipulation of discretionary expenses and the presence of an expert among the members of the audit committee for firms that have a low quality of governance. In contrast, Krishnan and Visvanathan (2008) find, for a sample of firms after SOX, that the presence of an expert in the audit committee can mitigate real earnings management.

Garven (2009) tests the impact of the characteristics of the board and audit committee on managing discretionary expenses. The author identified firms that engaged in these activities to avoid losses publication as a threshold. The study covered the post-SOX period from 2005 to 2007 for a sample of US companies listed on NYSE, AMEX and NASDAQ (S\&P 1500). The results showed that the possession of a company's shares by the independent members of a board of directors helped to align the interests of the board with shareholders. In addition, an excessive number of members serving on audit committee and board hinder the effectiveness of these two bodies. Garven (2009) showed that the board plays a limited role and the audit committee has no power over the opportunistic behaviour of managers in the case of real earnings management. According to the author, these results were mainly due to the lack of media coverage of practices like accounting manipulation and also to confusion between current manipulation and manipulation aimed to inflate short-term business results. In the same sense, Su et al. (2014) show that high additional members in audit committees worsen their monitoring effectiveness in constraining real earnings management.

Kang and Kim (2012) examine the impact of corporate governance on real earnings management, including the characteristics of the board of directors in the Korean context. The authors find that the relationship between real earnings management and board independence and board size is negative. The presence of an audit committee does not influence the level of real earnings management. They also develop an index of governance and verify endogeneity between real earnings management and the quality of governance. Thus, for companies making losses, the quality of governance does not affect the manipulation of real activities.

\section{Sample Description}

\section{RESEARCH DESIGN}

The main purpose of this study is to identify the impact of board characteristics on real earnings management. To achieve this, we collected a sample panel composed of companies listed on NASDAQ, AMEX and NYSE for the period 2000 to 2009. Financial data is collected from Compustat database, Board characteristics from RiskMetrics database and to calculate BONUS we used ExecuComp database. 
Table 1. Distribution of sample by year and industry

\begin{tabular}{lccccccccccc}
\hline Panel A: Distribution of sample by year \\
\hline Year & $\mathbf{2 0 0 0}$ & $\mathbf{2 0 0 1}$ & $\mathbf{2 0 0 2}$ & $\mathbf{2 0 0 3}$ & $\mathbf{2 0 0 4}$ & $\mathbf{2 0 0 5}$ & $\mathbf{2 0 0 6}$ & $\mathbf{2 0 0 7}$ & $\mathbf{2 0 0 8}$ & $\mathbf{2 0 0 9}$ & Total \\
Total & 287 & 577 & 663 & 685 & 714 & 764 & 858 & 981 & 990 & 962 & $\mathbf{7 4 8 1}$ \\
\hline
\end{tabular}

Panel B: Distribution of sample by industry

\begin{tabular}{lc}
\hline Industry & Total \\
\hline Manufacturing & 4684 \\
Retail trade & 779 \\
Services & 1354 \\
Wholesale trade & 297 \\
Mining & 367 \\
\hline Total & $\mathbf{7 4 8 1}$ \\
\hline
\end{tabular}

To form a homogeneous sample, we excluded financial firms (SIC codes: 6000-6999) and regulated firms (SIC codes: 4400-5000) insofar as they obey the rules well regarding the presentation of financial statements. We eliminated from our main sample observations missing data for the calculation of real earnings management and control variables. Negative sales or sales equal to zero and observations whose total assets were equal to zero were excluded. We also excluded all observations with firm-year sectors (according to the first two SIC codes) with less than 15 observations in a given year.

Our sample is composed of 7,481 observations. We find that 157 firms had incentives to manage earnings upward, i.e., firms that aimed to meet or beat earnings benchmarks (zero earnings, previous year's earnings).

\section{Empirical Models}

\section{Measure Of Real Earnings Management:}

In this study, we follow Roychowdhury (2006) and Cohen et al. (2008) in defining our three proxies of real earnings management (sales manipulation, discretionary expenses and overproduction). As in these two papers, abnormally low levels of cash flow and discretionary expenses and high levels of production costs are considered as indicators of upward real activities manipulation.

\section{(1) Sales Manipulation Or Abnormal Operating Cash Flow}

According to Roychowdhury (2006), handling sales is a technique that aims to increase the volume of sales for the current period, following the introduction of discounts and favourable payment terms. This technique helps to reduce the receipts of a company. Therefore, it greatly reduces the level of operating cash flow.

An abnormal level of cash flow from operations (Ab_CFO) is the difference between the actual cash flow from operations and the cash flow's normal operation. This model is estimated for each year t from 2000 to 2009 and for each sector (identified by the first two SIC codes) with at least 15 observations (first two SIC codes-year) using the following regression model:

Where

$$
\frac{\mathrm{CFO}_{i, t}}{A T_{i, t-1}}=\alpha_{1} \frac{1}{A T_{i, t-1}}+\alpha_{2} \frac{\text { Sales }_{i, t}}{A T_{i, t-1}}+\alpha_{3} \frac{\Delta \text { Sales }_{i, t}}{A T_{i, t-1}}+\varepsilon_{i, t}
$$

CFO: operating cash flow,

$\boldsymbol{A T}$ : total assets and

Sales: net sales. 


\section{(2) Overproduction}

Managers of industrial enterprises, which have a low sensitivity of demand with respect to price, may use overproduction to manage their results. The principle of this technique is to produce more than the normal amount. Then, general fixed costs are spread over a large number of units, and, in this case, the fixed costs of production will be absorbed and reduce the fixed cost per unit. Therefore, the cost of goods sold will decrease automatically generating a greater operating margin (Roychowdhury, 2006). However, such a company will incur additional costs of production and relative storage costs generated by the additional production not sold. Therefore, the operating cash flow will be lower than the normal level in relation to sales. All things being equal, the marginal cost of production and additional storage will result in increased production costs compared to annual sales.

The abnormal level of production (Ab_PROD) is estimated for each year $\mathrm{t}$ from 2000 to 2009 and for each sector (identified by the first two SIC codes) with at least 15 observations (first two SIC codes-year) by the following regression model:

$$
\frac{\text { PROD }_{i, t}}{A T_{i, t-1}}=\alpha_{1} \frac{1}{A T_{i, t-1}}+\alpha_{2} \frac{\text { Sales }_{i, t}}{A T_{i, t-1}}+\alpha_{3} \frac{\text { SAles }_{i, t}}{A T_{i, t-1}}+\alpha_{4} \frac{\text { SAles }_{i, t-1}}{A T_{i, t-1}}+\varepsilon_{i, t}
$$

Where

$$
P R O D_{i, t}=\operatorname{COGS}_{i, t}+\Delta I N V T_{i, t}
$$

PROD: production costs equal to the cost of goods sold (COGS) and inventory variation ( $\triangle$ INVT), $\boldsymbol{A T}$ : total assets and

Sales: net sales

\section{(3) Manipulation Of Discretionary Expenses}

Discretionary expenses are paid in the same period they are incurred. To meet its short-term objectives of increasing its profit for the current year, a company can reduce discretionary spending by the reducing expenditures reported. Indeed, these expenses do not generate immediate revenue; they are in the form of cash, and, therefore, reducing such spending reduces cash outflows, increasing the cash flow from operations for the current period (Roychowdhury, 2006).

An abnormal level of discretionary spending (Ab_DISC) is estimated for each year $\mathrm{t}$ from 2000 to 2009 and for each sector (identified by the first two SIC codes) with at least 15 observations (first two SIC codes-year) by the following regression model:

$$
\frac{\operatorname{DISC}_{i, t}}{A T_{i, t-1}}=\alpha_{1} \frac{1}{A T_{i, t-1}}+\alpha_{2} \frac{\text { Sales }_{i, t-1}}{A T_{i, t-1}}+\varepsilon_{i, t}
$$

Where

$$
D I S C=R \& D+\text { Advertising }+ \text { Selling, general and administrative expenses }
$$

DISC: discretionary expenses,

AT: total assets and

Sales: net sales.

\section{(4) Total Real Earnings Management}

We establish a global measurement of real earnings management. Residual values of models (A) and (C) are multiplied by $(-1)$ because, when handling sales and/or discretionary expenses, actual operating cash flows and 
actual discretionary expenses are less than operating cash flows and discretionary expenses estimated. To bring changes in various processes into a single unit (Cohen et al., 2008; Cohen and Zarowin, 2010; Chi et al., 2011), this measure is the sum of all the operations of the three standardized residuals. The larger this measure, the greater the degree of manipulation of the real activities of a company. We calculate real earnings management by the following regression:

$$
R E M_{i, t}=-S R\left(A b_{-} C F O_{i, t}\right)+S R\left(A_{-} P R O D_{i, t}\right)-S R\left(A b_{-} D I S C_{i, t}\right)
$$

Where

REM: real earnings management,

$\boldsymbol{A} \boldsymbol{b} \_\boldsymbol{C F O}$ : abnormal level of operating cash flow (the residual of model A),

Ab_PROD: abnormal level of production (the residual of model B) and,

Ab_DISC: abnormal level of discretionary expenses (the residual of model C).

Model Of The Impact Of Board Characteristics On Real Earnings Management

$$
R E M_{i, t}=\alpha_{0}+\alpha_{1}(B C * S U S P E C T)_{i, t}+\alpha_{2} T A I L_{i, t}+\alpha_{3} L E V_{i, t}+\alpha_{4} M B_{i, t}+\alpha_{5} R O A_{i, t}+\alpha_{6} B O N_{i, t}+\varepsilon_{i, t}
$$

Where

REM: the composite measure of all standardized real activities manipulation and BC: board characteristic.

\section{Board Of Directors}

The board of directors is considered as a vital organ of internal corporate governance. In this study, we consider two features of the board of directors: board size (NDIR) and independence (BOARD_IND). Two main functions are assigned to the board of directors, namely, the evaluation and ratification of decisions and control management (Fama and Jensen, 1983). Through its functions, the board protects the interests of shareholders and helps managers to undertake strategies and appropriate decisions.

NDIR: the size of the board. The size of the board has been subject to various criticisms, which relate to the search for an optimal size. Proponents of agency theory hold that the more the optimal size of the board is reduced the easier will be internal communication and decision making (Fama, 1980; Fama and Jensen, 1983; Jensen, 1993; Yermack, 1996). For followers of the theory of resource dependence, they prefer large board. Indeed, the presence of a large number of directors, each with specific knowledge, favours favourable transactions between firms (Pearce and Zahra, 1992).

HYPOTHESIS 1: The Relation Between Board Size And Real Earnings Management Is Positive.

BORD_IND: the independence of the board. This is the number of independent directors divided by board size. Shleifer and Vishny (1997) argue that the structure of a board is a key element of its effectiveness. According to agency theory, the presence of independent directors can mitigate agency conflicts and thus the managerial opprtunism. These directors are forced to improve their reputations in the labour market (Fama, 1980). However, some studies question the effectiveness of boards dominated by outside members. Indeed, outside directors have less information than internal members. The special character of the real earnings management technique requires a detailed knowledge of the internal operations of a company.

HYPOTHESIS 2: The relation between board independence and real earnings management is negative. 


\section{Board Committees}

AUD_IND: a binary variable that takes 1 if the members of an audit committee are independent and 0 otherwise. The primary role of an audit committee is to ensure reliable financial and accounting information and to follow this through the development of financial reporting and the monitoring of the effectiveness of internal control systems. Klein (2002) finds that the relationship between the independence of the audit committee and the management of discretionary accruals is negative and significant.

HYPOTHESIS 3: The relation between audit committee independence and real earnings management is negative.

NOM_IND: a binary variable that takes 1 if the members of a nominating committee (or selection) of the directors are independent and 0 otherwise. The committee's role is proposing candidates for the board of directors and various committees. It is the most vital organ that ensures the independence of the board and all committees. Kouki et al. (2011) suggest that the independence of the nominating committee reduces earnings management.

HYPOTHESIS 4: The relation between nominating committee independence and real earnings management is negative.

COMP_IND: a binary variable that takes 1 if the members of a compensation committee are independent and 0 otherwise. The principal role of the compensation committee is to make recommendations to the board of directors on the remuneration policy for directors and on incentive policies.

HYPOTHESIS 5: The relation between compensation committee independence and real earnings management is negative.

GOV_IND: a binary variable that takes 1 if the members of a governance committee are independent and 0 otherwise. This committee is responsible for the annual evaluation of the board and various committees. It also assists the board in carrying out annual reviews of the quality and supervision of business conduct and of adequate disclosure of information. Huang et al. (2009) find that firms that are able to resolve severe agency problems have governance committees. In addition, they find that totally independent governance committees do not have an effect on earnings management.

HYPOTHESIS 6: The relation between governance committee independence and real earnings management is negative.

SUSPECT: an indicative variable that takes 1 if a firm has strong incentives to manage earnings upward, i.e., a firm that meets or just beats one of two earnings benchmarks (zero earnings, previous year's earnings) ${ }^{1}$.

TAIL: the natural $\log$ of total assets.

LEV: the leveraged ratio of total liabilities to total assets.

MB: the market to book ratio.

ROA: the return on assets ratio, the ratio of earnings before ordinary items to total assets at the end of a period.

BON: average bonus compensation as a proportion of total compensation received by a CEO.

\footnotetext{
${ }^{1}$ As Roychowdhury (2006), we define firms that meet or beat zero earnings benchmarks if their net income scaled by total assets at the beginning of a year falls into the interval $[0,0.005]$ and firms that meet or beat a previous year's earnings benchmarks if their change in net income scaled by total assets at the beginning of the year falls into the interval between $[0,0.005]$.
} 


\section{EMPIRICAL RESULTS}

\section{Univariate Results}

Table 2 provides descriptive statistics. Panel A in Table 2 provides descriptive statistics for estimated coefficients and adjusted $\mathrm{R}^{2}$ of real earnings management models (Abn_CFO, Abn_Prod and Abn_Discexp). Models A, B and C were estimated by industry (two digit-SIC code) and year; firms with fewer than 15 observations were eliminated from the sample. There are 531 such industry-year groups from 2000 to 2009 . The sign of our estimated coefficients are similar to those reported in seminal Roychowdhury's (2006) study on real earnings management. Respectively the Mean of adjusted $\mathrm{R}^{2}$ for Ab_CFO, Ab_PROD and Ab_DISC are about $70.37 \%, 95.69 \%$ and $79.06 \%$.

Table 2. Descriptive Statistics

Panel A: Descriptive statistics for estimated coefficients and adjusted $R^{2}$ of real earnings management models Distribution of estimated coefficients and $\mathbf{R}^{2} \mathbf{s}$ from Model (A) to calculate Ab_CFO

\begin{tabular}{|c|c|c|c|c|c|}
\hline & \multicolumn{5}{|c|}{$\mathrm{CFO} \mathrm{AT}_{\mathrm{i}, \mathrm{t}-1}$} \\
\hline & Mean & Std. Dev & Q1 & Median & Q3 \\
\hline $\mathbf{1} / \mathbf{A} \mathbf{T}_{\mathrm{i}, \mathrm{t}-1}$ & $\begin{array}{c}-1.7514 \\
(-1.31)\end{array}$ & 17.7937 & -10.3513 & -1.6203 & 6.9916 \\
\hline Sales $_{i, t} / A T_{i, t-1}$ & $\begin{array}{c}0.0949 \\
(23.24)^{* * *}\end{array}$ & 0.0543 & 0.0649 & 0.0904 & 0.1154 \\
\hline$\Delta$ Sales $_{i, t} / \mathbf{A T}_{\mathrm{i}, \mathrm{t}-1}$ & $\begin{array}{c}0.0824 \\
(7.21)^{* * *}\end{array}$ & 0.1520 & -0.0204 & 0.0718 & 0.1812 \\
\hline Adjusted $\mathbf{R}^{2}$ & 0.7037 & 0.1645 & 0.6109 & 0.7378 & 0.8236 \\
\hline
\end{tabular}

Distribution of estimated coefficients and $\mathbf{R}^{2}$ s from Model (A) to calculate Ab_PROD

\begin{tabular}{|c|c|c|c|c|c|}
\hline & \multirow[b]{2}{*}{ Mean } & \multirow[b]{2}{*}{ Std. Dev } & \multicolumn{3}{|c|}{ PROD/AT $_{\mathrm{i}, \mathrm{t}-\mathbf{1}}$} \\
\hline & & & Q1 & Median & Q3 \\
\hline $\mathbf{1} / \mathbf{A} \mathbf{T}_{\mathrm{i}, \mathrm{t}-\mathbf{1}}$ & $\begin{array}{c}-21.0285 \\
(-4.42) * * *\end{array}$ & 63.3169 & -28.9523 & -12.1835 & 2.3404 \\
\hline Sales $_{\mathrm{i}, \mathrm{t}} / \mathbf{A T}_{\mathrm{i}, \mathrm{t}-1}$ & $\begin{array}{c}0.6961 \\
(90.65)^{* * *}\end{array}$ & 0.1021 & 0.6480 & 0.7052 & 0.7518 \\
\hline$\Delta$ Sales $_{\mathrm{i}, \mathrm{t}} / \mathrm{AT}_{\mathrm{i}, \mathrm{t}-1}$ & $\begin{array}{c}0.0450 \\
(1.58)\end{array}$ & 0.3802 & -0.1556 & 0.0478 & 0.2220 \\
\hline$\Delta$ Sales $_{\mathrm{i}, \mathrm{t}-1} / \mathrm{AT}_{\mathrm{i}, \mathrm{t}-1}$ & $\begin{array}{l}-0.0494 \\
(-1.74)^{*}\end{array}$ & 0.3779 & 0.2262 & -0.0502 & 0.0783 \\
\hline Adjusted $\mathbf{R}^{2}$ & 0.9569 & 0.0388 & 0.9414 & 0.9728 & 0.9850 \\
\hline
\end{tabular}

Distribution of estimated coefficients and $\mathbf{R}^{2}$ s from Model (A) to calculate Ab_DISC

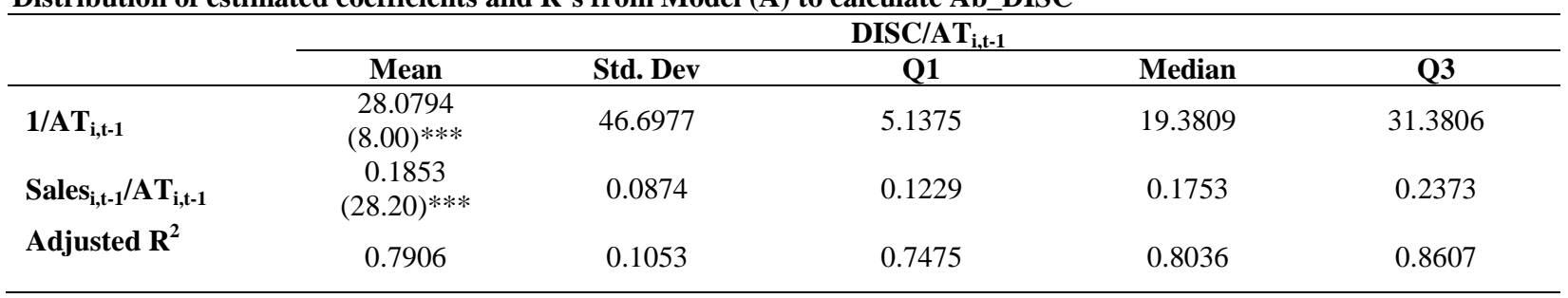

Panel B: Descriptive statistics of binary variables

\begin{tabular}{lccc}
\hline & Mean & Std. dev & Min \\
\hline AUD_IND & 0,8990 & 0,3013 & 0 \\
COMP_IND & 0,8900 & 0,3128 & 0 \\
NOM_IND & 0,8149 & 0,3883 & 0 \\
GOV_IND & 0,8097 & 0,3925 & 0 \\
\hline
\end{tabular}


(Table 2 continued)

Panel C: Descriptive statistics for continuous variables

\begin{tabular}{lccccc}
\multicolumn{1}{c}{ Variables } & Mean & Std. Dev & Q1 & Median & Q3 \\
\hline REM & 0.0079 & 2.2255 & -1.3440 & 0.0547 & 1.2684 \\
Ab_CFO & 0.0146 & 0.0851 & -0.0352 & 0.0126 & 0.0652 \\
Ab_PROD & -0.0300 & 0.1756 & -0.1337 & -0.0310 & 0.0673 \\
Ab_DISC & 0.0186 & 0.1423 & -0.0598 & 0.0125 & 0.0945 \\
NDIR & 8.8201 & 2.2338 & 7 & 9 & 10 \\
BOARD_IND & 0.7243 & 0.1488 & 0.6250 & 0.7500 & 0.8461 \\
TAIL & 7.2288 & 1.4538 & 6.1637 & 7.0753 & 8.1549 \\
LEV & 0.1591 & 0.1515 & 0.0022 & 0.1360 & 0.2605 \\
MB & 2.9917 & 2.3911 & 1.5363 & 2.3299 & 3.6641 \\
ROA & 0.0461 & 0.0974 & 0.0208 & 0.0573 & 0.0958 \\
BON & 0.1104 & 0.1494 & 0 & 0.0206 & 0.1904 \\
\hline AllCON
\end{tabular}

All continuous variables are winsorisées $2 \%$.

Panels B and C in Table 2 provide descriptive statistics of binary and continuous variables of our model. The mean of REM is 0.0079 . The variable size is volatile with a standard deviation of 1.4538 and a mean of 7.2288. The financial leverage ratio has a mean (median) of $15.91 \%(15.15 \%)$. The average profitability of the assets of firms in our sample is positive $(4.61 \%)$, which means that, on average, these companies are profitable. Variable market to book (MB), which measures growth opportunities, is volatile around its standard deviation (mean), which is 2.3911 (2.9917). The mean (median) of variable BON is $0.1104(0.1494)$. On average, the managers of our sample receive $11 \%$ incentive compensation relative to their total compensation, which is important. This partly explains their behaviour as 'opportunistic'.

\section{Multivariate Analysis}

The estimation results are provided in Table 3. All t-statistics are calculated using two-way clusters (by industry and year) to take into consideration heteroscedasticity and serial correlation (Petersen, 2009) In the first three columns reports each of the three components (Ab_CFO, Ab_PROD and Ab_DISC) of the composite of real earnings management measure (REM), separately, as dependent variables. While the last column reports the results of the impact of board of directors on overall real activities manipulations (REM).

We find a positive and significant coefficient of $0.67(\mathrm{t}=3.77)$ on NDIR in the REM regression. Consistent with the component of REM, all coefficients are also positive and significant and are about 0.56 $(\mathrm{t}=2.86), 0.09$ $(\mathrm{t}=3.45)$ and $0.4(\mathrm{t}=3.97)$ respectively for NDIR in Ab_CFO, Ab_DISC and Ab_PROD regressions. These results corroborate with the agency theory point of view, suggesting that a small board composition contribute to increase his monitoring effectiveness (Jensen, 1993; Yermack, 1996). In fact, the followers of this theory sustain the idea that large size of the board may create difficulties in communication and coordination between different directors, which make the process making decision heavy and less effective. Thus, a large board allows favoring the dominance of the executive in place, which involves coalitions and conflicts of interest between the different directors. Therefore, the board will be fragmented and inefficient. These results seem to be in disagreement with the others empirical works. For example, Visvanathan (2008) and Graven (2009) don't detect association between board size and real earnings management, while Kang and Kim (2012) find a negative one. 
Table 3. Impact of board of director characteristics on real earnings management

\begin{tabular}{|c|c|c|c|c|}
\hline Variables & Ab_CFO & Ab_DISC & Ab_PROD & REM \\
\hline Intercept & $\begin{array}{c}1.34 \\
(5.54)^{* * *}\end{array}$ & $\begin{array}{c}1.23 \\
(4.81)^{* * *}\end{array}$ & $\begin{array}{c}1.14 \\
(4.82)^{* * *}\end{array}$ & $\begin{array}{c}1.16 \\
(5.51)^{* * *}\end{array}$ \\
\hline NDIR * SUSPECT & $\begin{array}{c}0.56 \\
(2.68)^{* * *}\end{array}$ & $\begin{array}{c}0.09 \\
(3.45)^{* * *}\end{array}$ & $\begin{array}{c}0.4 \\
(3.97)^{* * *}\end{array}$ & $\begin{array}{c}0.67 \\
(3.77)^{* * *}\end{array}$ \\
\hline $\begin{array}{l}\text { BOARD_IND * } \\
\text { SUSPECT }\end{array}$ & $\begin{array}{c}-0.47 \\
(-2.26)^{* *}\end{array}$ & $\begin{array}{c}-0.01 \\
(-4.78)^{* *}\end{array}$ & $\begin{array}{c}0.76 \\
(4.62)^{* *}\end{array}$ & $\begin{array}{c}-0.56 \\
(-3.66)^{* *}\end{array}$ \\
\hline AUDIT_IND * & -0.02 & -0.19 & -0.32 & -0.43 \\
\hline SUSPECT & $(-0.12)$ & $(-0.50)$ & $(-0.01)$ & $(-0.01)$ \\
\hline COMP_IND * & -0.06 & -0.01 & -0.43 & -0.28 \\
\hline SUSPECT & $(-0.71)$ & $(-0.63)$ & $(-0.82)$ & $(-0.56)$ \\
\hline NOM_IND * & 0.02 & 0.04 & 0.19 & 0.83 \\
\hline SUSPECT & $(0.13)$ & $(0.29)$ & $(0.72)$ & $(0.70)$ \\
\hline GOV_IND * & 0.02 & 0.34 & 0.74 & 0.46 \\
\hline SUSPECT & $(0.16)$ & $(0.71)$ & $(0.59)$ & $(0.13)$ \\
\hline TAIL & $\begin{array}{c}-0.12 \\
(-4.07)^{* * *}\end{array}$ & $\begin{array}{c}-0.10 \\
(-4.00)^{* * *}\end{array}$ & $\begin{array}{c}-0.13 \\
(-4.01)^{* * *}\end{array}$ & $\begin{array}{c}-0.09 \\
(-3.89) * * *\end{array}$ \\
\hline LEV & $\begin{array}{c}1.43 \\
(5.93)^{* * *}\end{array}$ & $\begin{array}{c}1.48 \\
(6.01)^{* * *}\end{array}$ & $\begin{array}{c}1.62 \\
(6.10)^{* * *}\end{array}$ & $\begin{array}{c}1.49 \\
(6.06)^{* * *}\end{array}$ \\
\hline MB & $\begin{array}{c}-0.24 \\
(-16.07)\end{array}$ & $\begin{array}{c}-0.29 \\
(-15.90) * * *\end{array}$ & $\begin{array}{c}-0.26 \\
(-16.93)^{* * *}\end{array}$ & $\begin{array}{c}-0.23 \\
(-15.64) * * *\end{array}$ \\
\hline ROA & $\begin{array}{c}-3.40 \\
(-6.98)^{* * *}\end{array}$ & $\begin{array}{c}-3.32 \\
(-6.79)^{* * *}\end{array}$ & $\begin{array}{c}-3.35 \\
(-6.38)^{* * *}\end{array}$ & $\begin{array}{c}-3.31 \\
(-6.79)^{* * *}\end{array}$ \\
\hline BON & $\begin{array}{c}0.14 \\
(0.61) \\
\end{array}$ & $\begin{array}{c}0.19 \\
(0.87) \\
\end{array}$ & $\begin{array}{c}0.20 \\
(0.80) \\
\end{array}$ & $\begin{array}{c}0.18 \\
(0.83) \\
\end{array}$ \\
\hline Adjusted R ${ }^{2}$ & 0.23 & 0.25 & 0.21 & 0.27 \\
\hline Fisher & $57.82 * * *$ & $60.00 * * *$ & $53.98 * * *$ & $71.98 * * *$ \\
\hline
\end{tabular}

***, ** and *, indicate significance respectively at $1 \%, 5 \%$ and $10 \%$. All t-statistics are calculated using two way clusters (industry and year) to take in consideration for heteroscedasticity and serial correlation (Petersen 2009).

Furthermore, we find a negative and significant coefficient of $-0.56(\mathrm{t}=-3.66)$ on BOARD_IND in the REM regression. Consistent with the component of REM all coefficients are significant and mixed. We find a negative coefficient of $-0.47(\mathrm{t}=-2.26)$, a negative coefficient of $-0.01(\mathrm{t}=-4.78)$ and a positive coefficient of $0.76(\mathrm{t}=4.62)$ on BOARD_IND in Ab_CFO, Ab_DISC and Ab_PROD regressions. These results suggest that higher board independence is associated with lower level of real activities manipulation. Consistent with the components of the proxy of real earnings management, we find that board independence is associated with lower abnormal cash flow, lower discretionary expenses and higher abnormal production. Jointly, these results suggest that higher board independence is associated with a lower level of real earnings management. This result is consistent with the findings of some previous empirical studies (Visvanathan, 2008; Kang and Kim, 2012). Thus, the higher presence of independent directors in the board could constrain the managerial opportunistic behavioral and enhances the role of board control effectiveness.

We find also that coefficients of the independence of different board committees (AUD_IND, COMP_IND, NOM_IND and GOV_IND) on the overall real earnings management proxy (REM) and on all its components (Ab_CFO, Ab_DISC, Ab_PROD) are insignificant at the conventional levels. These results imply that the committees are inefficient to detect and so to constrain real activities manipulations. These findings are consistent with the major empirical studies that have addressed the relationship between the independence of the committees of the board and the level of real earnings management (Carcello et al., 2008; Graven, 2009; Huang et al., 2009; Kang and Kim, 2012; Su et al., 2014). This is consistent with the evidence that real activities manipulations are very specific to be detected because it occurrence over the year, contrary to the accruals manipulation that arises at the end of the year. It cannot be distinguishable from current ordinary operations. In table 3, for the control variables we show that the variable real earnings management (REM) is positively and significantly associated with the size of the firm (SIZE), market to book (MB) and return on assets (ROA), while it is positively and significantly associated with leverage (LEV) and bonus (BON). 
Finally, in the case of our sample (SOX) the independence of the board and committees is required by law. Our results clearly demonstrate that directors can comply with the law by increasing the number of independent members of the board that are, at the same time, close to management. We can, therefore, conclude that the structures imposed by the laws have lead officers to engage in inefficient control structures.

\section{CONCLUSION}

The purpose of this article is to verify the impact of the independence of the board and committees on real earnings management. In this research, we are motivated by the assumption that good corporate governance leads to increased manager opportunism. Our empirical results show that only an independent board of directors can mitigate the level of real earnings management. In addition, the relation between the size of the board and real earnings management is positive, while completely independent board committees have no effect on the level of real earnings management. These results suggest that, when a board of directors is sufficiently independent, the need to establish independent committees might be unnecessary.

Our study contributes to empirical studies concerned with the role of corporate governance in financial reporting quality by demonstrating the role of the independence of both the board of directors and committees in constraining real earnings management. This study should contribute to providing an orientation for future regulators regarding possible amendments, especially in the wake of the current financial crisis, and a way to revise laws that have been previously introduced.

\section{AUTHOR INFORMATION}

Dorra Talbi, assistant at Institut Supérieur d'Informatique et de Gestion de Kairouan, Tunisia. Associated at Laboratory of Gouvernance d'Entreprise, Finance Appliquée et Audit GEF2A (ISG de Tunis, Tunisia) and at IPAG Research Lab (France). Her research interests are related to financial reporting, voluntary disclosure, cost of capital, audit and corporate governance. Email: talbi.dorra@gmail.com

Zied Ftiti, Professor, EDC Paris Business School, OCRE-Lab, Paris-France \& Associate Professor, Higher Institute of Management, Department of Economics and quantitative methods, Tunis-Tunisia. E-mail: Zied.Ftiti@edcparis.edu (Corresponding author)

Mohamed Ali Omri, Full Professor of Accounting at the College of Business Administration, Northern Border University (Kingdom of Saudia Arabia). He is directing several PhD theses in accounting, audit, corporate governance, taxation and finance. He is also the author of two books on taxation of Tunisian companies and several articles on taxation accounting, auditing and corporate governance. E-mail: Medomri@gmail.com

Khaled Guesmi, is Professor at the IPAG Business School and is a specialist in quantitative studies. His main research areas are quantitative finance and econometrics. E-mail: khaled.guesmi@ipag.fr

\section{REFERENCES}

Carcello, J., Hollingsworth, C., Klein, A. and Neal, T. (2008) “Audit committee financial expertise, competing corporate governance mechanisms, and earnings management", working paper, University of Tennessee, Clemson University, and New York University.

Chan, L-H., Chen, K-C-W., Chen, T-W., and Yu, Y. (2014) "Substitution between Real and Accruals-Based Earnings Management after Voluntary Adoption of Compensation Clawback Provisions" The Accounting Review, In-Press.

Chi, W., Lisic, L.L. and Pevzner, M. (2011) "Is enhanced audit quality associated with greater real earnings management?” Accounting Horizons, Vol. 25, No. 2, pp. 315-335.

Cohen, D. and Zarowin, P. (2010) “Accrual-based and real earnings management activities around seasonal equity offerings" Journal of Accounting and Economics, Vol. 50, No. 1, pp 2-19.

Cohen, D.A., Dey, A. and Lys, T.Z. (2008) "Real and accrual-based earnings management in the pre- and postSarbanes Oxley periods" The Accounting Review, Vol. 83, pp. 757-787. 
Demski, J. (2004) "Endogenous expectations" The Accounting Review, Vol. 79, pp. 519-539.

Ewert, R. and Wagenhofer. A. (2005) "Economic effects of tightening accounting standards to restrict earnings management" The Accounting Review, Vol. 80, pp. 1101-24.

Fama, E.F. (1980) "Agency problems and the theory of the firm" Journal of Political Economy, Vol. 88, pp. 288 307.

Fama, E.F. and Jensen, M.C. (1983) "Separation of ownership and control" Journal of Law and Economics, Vol. 26, pp. 301-325.

Garven, S. (2009) "The effect of board and audit committee characteristics on real earnings management: Do boards and audit committees play a role in its constraint?" working paper, University of Alabama.

Ge, W. and Kim, J-B. (2014) "Real earnings management and the cost of new corporate bonds" Journal of Business Research, Vol. 67, No. 4, pp. 641-647.

Graham, J., Harvey, C.R. and Rajgopal, S. (2005) "The economic implications of corporate financial reporting" Journal of Accounting and Economics, Vol. 40, No. 1-3, pp. 3-73.

Gunny, K. (2005) "What are the consequences of real earnings management?" working paper, University of Colorado.

Gunny, K. (2010) "The relation between earnings management using real activities manipulation and future performance: Evidence from meeting earnings benchmarks" Contemporary Accounting Research, Vol. 27 No. 3, pp. 855-888.

Healy, P.M. and Wahlen, J.M. (1999) "A review of the earnings management literature and its implications for standard setting" Accounting Horizons, Vol. 13 No. 4, pp. 365-383.

Huang, H., Lobo, G. and Zhou, J. (2009) "Determinants and accounting consequences of forming a governance committee: Evidence from the United States" Corporate Governance: An International Review, Vol. 17 No. 6, pp. 710-727.

Jensen, M.C. (1993) “The modern industrial revolution, exit, and the failure of internal control systems" Journal of Finance, Vol. 48, pp. 831-880.

Kang, S.A. and Kim, Y.S. (2012) "Effect of corporate governance on real activity-based earnings management: Evidence from Korea" Journal of Business Economics and Management, Vol. 13 No. 1, pp. 29-52.

Kim, B. Lisic, L.L. and Pevzner, M. (2010) "Debt covenant slacks and real earnings management”, working paper, George Mason University.

Klein, A. (2002) "Audit committee, board of director characteristics, and earnings management" Journal of Accounting and Economics, Vol. 33, pp. 375-400.

Kothari, S.P., Leone, A. and Wasley, C.E. (2005) "Performance matched discretionary accrual measures" Journal of Accounting and Economics, Vol. 39, pp. 163-197.

Kouki, M., Elkhaldi, A. and Souid, S. (2011) "Does corporate governance constrain earnings management? Evidence from U.S. firms" European Journal of Economics, Finance and Administrative Sciences, Vol. 35, pp. 59-68.

Krishnan, G. and Visvanathan, G. (2008) "Does the SOX definition of an accounting expert matter? The association between audit committee directors' accounting expertise and accounting conservatism" Contemporary Accounting Research, Vol. 25, pp. 827-857.

Kuo, J-M., Ning, L. and Song, X. (2014) "The Real and Accrual-based Earnings Management Behaviors: Evidence from the Split Share Structure Reform in China” The International Journal of Accounting, Vol. 49, No. 1, pp. 101-136.

Osma, B.G. (2008) "Board independence and real earnings management: The case of R\&D expenditure" Corporate Governance: An International Review, Vol. 16 No. 2, pp. 116-131.

Pearce, J.A. and Zahra, S.A. (1992) "Board composition from a strategic contingency perspective" Journal of Management Studies, Vol. 29, pp. 411-439.

Petersen, M. (2009) "Estimating standard errors in finance panel data sets: Comparing approaches" Review of Financial Studies, Vol. 22 No. 1, pp. 435-480.

Roychowdhury, S. (2006) "Earnings management through real activities manipulation" Journal of Accounting and Economics, Vol. 42, pp. 335-370.

Shleifer, A. and Vishny, R.W. (1997) "A survey of corporate governance” Journal of Finance, Vol. 52, pp. 737-83.

Sun, J., Lan, G. and Liu, G. (2014) "Independent audit committee characteristics and real earnings management", Managerial Auditing Journal, Vol. 29, No. 2, pp. 153 - 172. 
Visvanathan, G. (2008) "Corporate governance and real earnings management" Academy of Accounting and Financial Journal, Vol. 12, No. 1, pp. 9-22.

Watts, R.L. and Zimmerman, J.L. (1990) "Positive Accounting Theory: A Ten Year Perspective" The Accounting Review, Vol. 65, No.1, pp. 131-156.

Yermack, D. (1996) "Higher market valuation of companies with a small board of directors" Journal of Financial Economics, Vol. 40, pp. 185-212.

Zang, A-Y. (2012) "Evidence on the tradeoff between real manipulation and accrual manipulation". The Accounting Review,Vol. 87, pp. 675-703. 